ANUARIO DE Estudios Medievales 51/1, enero-junio de 2021, pp. 269-301

ISSN 0066-5061

https://doi.org/10.3989/aem.2021.51.1.09

\title{
RODRIGO JIMÉNEZ DE RADA Y LA VALORACIÓN DEL PATRIMONIO DE AL-ANDALUS COMO ALGO PROPIO. ARABIZACIÓN E ISLAMIZACIÓN
}

\author{
RODRIGO JIMÉNEZ DE RADA AND THE EVALUATION OF ANDALUSIAN ART \\ IN ITS OWN RIGHT. ARABISATION AND ISLAMISATION
}

JUAN CARLOS RUIZ SOUZA

Universidad Complutense de Madrid

https://orcid.org/0000-0001-6463-5687h

\begin{abstract}
Resumen: En el presente artículo abordamos las circunstancias que hicieron posible la valoración de la arquitectura andalusí y su conservación. El arzobispo de Toledo D. Rodrigo Jiménez de Rada fue en gran medida el responsable de ello al entender que Hispania era consecuencia de una colectividad de pueblos que se suceden a lo largo de los siglos.

Palabras clave: Rodrigo Jiménez de Rada; Historia de Rebus Hispanie; Historia Arabum; San Román de Toledo; patrimonio de al-Andalus; Palacio de Brihuega; pintura de lo morisco o de "tirar cintas"; cúpula de mocárabes.

Abstract: This paper studies the circumstances which enabled the appreciation and preservation of the Andalusian architectural heritage. The Archbishop of Toledo, D. Rodrigo Jiménez de Rada, played an essential part in it, by understanding how Hispania was a collective project made up of different peoples over the course of the centuries.

Keywords: Rodrigo Jiménez de Rada; Historia de Rebus Hispanie; Historia Arabum; San Roman of Toledo; heritage of al-Andalus; Palace of Brihuega; pintura de lo morisco o de "tirar cintas"; muqarnas dome.
\end{abstract}

\section{SUMARIO}

1. Rodrigo Jiménez de Rada (1170-1247) y la renovación del paisaje monumental de Castilla y León y de al-Andalus.- 2. Conservación y memoria del patrimonio de alAndalus en la Corona de Castilla y León.- 3. ¿De dónde partimos? Aspectos artísticos coincidentes en la construcción de identidades. Córdoba, Asturias y Sevilla: siglos VIII-XII.- 4. Cuando el árabe y la cultura visual arabizada se convierten en señal de identidad cristiana: Rodrigo Jiménez de Rada y San Román de Toledo. Sinergias artísticas entre Toletum y Roma.- 5. ¿Hispania o Hispaniae? La Historia de Rebus Hispanie, la Historia Arabum y la razón de la ley dellos.- 6. El inicio de un nuevo comportamiento en la asunción del arte andalusí: Brihuega y Toledo.- 7. Reflexión final. Arabización e Islamización. Algo que forma parte de la Estoria de España nunca podrá ser botín o trofeo, pero sí testigo de su memoria. Viabilidad de un proyecto aparentemente contradictorio.- 8 . Bibliografía citada.

Citation / Cómo citar este artículo: Ruiz Souza, Juan Carlos (2021), Rodrigo Jiménez de Rada y la valoración del patrimonio de al-Andalus como algo propio. Arabización e islamización, "Anuario de Estudios Medievales" 51/1, pp. 269-301. https://doi.org/10.3989/aem.2021.51.1.09

Copyright: (C) 2021 CSIC. Este es un artículo de acceso abierto distribuido bajo los términos de la licencia de uso y distribución Creative Commons Reconocimiento 4.0 Internacional (CC BY 4.0). 


\section{RODRIGO JIMÉNEZ DE RADA (1170-1247) Y LA RENOVACIÓN DEL PAISAJE MONUMENTAL DE CASTILLA Y LEÓN Y DE AL-ANDALUS ${ }^{1}$}

A lo largo de aquellas décadas en las que vivió Rodrigo Jiménez de Rada se produjo la inclinación de la balanza a favor de la Corona de Castilla frente al resto de monarquías hispanas en lo que a la hegemonía política en la península ibérica se refiere ${ }^{2}$. En 1212, en la batalla de las Navas de Tolosa, Castilla liderará la expansión hacia el sur frente a un al-Andalus en descomposición. Las grandes capitales de los dos califatos andalusíes, la Córdoba omeya y la Sevilla almohade, pasaron a integrarse en el territorio de la flamante corona de Castilla y León, unificada definitivamente bajo el cetro de Fernando III tras la muerte de su padre Alfonso IX de León. Rodrigo Jiménez de Rada puede convertirse en el hilo conductor de un periodo tan fecundo al ser un personaje de gran protagonismo político y religioso durante los reinados de Alfonso VIII y de Fernando III. A lo largo de sus casi ochenta años de vida lo encontramos estudiando en París, en varias ocasiones en Roma en donde participa en el IV Concilio de Letrán de 1215, o en las tierras de frontera con al-Andalus. Pocos personajes de la época de semejante importancia política pudieron participar en tantos acontecimientos, y desde luego difícilmente pudieron ver tantos paisajes monumentales, tan variados y tan distintos. Su nombre ha quedado vinculado al inicio de la catedral de Toledo, la fábrica gótica más importante de la península ibérica, pero esperamos que tras las próximas páginas le veamos también como la piedra angular que diseñó los cimientos intelectuales que permitieron la conservación del patrimonio arquitectónico de al-Andalus.

A lo largo de la dilatada vida del que fuera arzobispo de Toledo desde 1209, el paisaje monumental de los territorios de la Castilla y León, así como el de al-Andalus, cambió y se renovó con algunas de las obras más importantes del medievo que todavía hoy disfrutamos. El Pórtico de la Gloria de la catedral de Santiago de Compostela, la Giralda de Sevilla, el inicio de las fábricas del monasterio de las Huelgas Reales de Burgos y de la catedral de Cuenca, la renovación de la catedral de Ávila, o el inicio de las grandes catedrales de Burgos y Toledo, nos hablan de un periodo fascinante de adaptación, revolución y cambios artísticos. Todo ello ha constituido

\footnotetext{
${ }^{1}$ Queremos dar las gracias a Marta Poza Yagüe, Susana Calvo Capilla, Carmen Rallo Gruss y Carlos de Ayala Martínez por las conversaciones con ellos mantenidas durante la realización del presente artículo.

${ }^{2}$ Sería interminable intentar citar todos los trabajos que han abordado la figura y obra de Jiménez de Rada, nosotros partimos de los siguientes: Gorosterratzu 1925; Grassotti 1972; Lomax 1977; Fernández 1995; Fernández-Ordóñez 2000; Pick 2004; Dodds 2007; Bravo 2019.
} 
uno de los hitos historiográficos más dinámico y fecundo de la historia del arte medieval hispano y, a modo de intenso foco de luz, podríamos decir incluso que nos ha deslumbrado sin posibilidad de ver aspectos esenciales que se produjeron en aquellos años referidos a la Historia del Arte.

\section{CONSERVACIÓN Y MEMORIA DEL PATRIMONIO DE AL-ANDALUS EN LA CORONA DE CASTILLA Y LEÓN}

Mediante cédula real con fecha de 13 de diciembre de 1263, Alfonso X mandaba que los "moros" residentes en la ciudad de Córdoba dedicados a la construcción (albañiles, herreros y carpinteros) trabajasen según su oficio en la catedral dos días al año por grand sabor que auemos que la noble iglesia de Sancta María de la cibdat de Córdoua sea más guardada et que non pueda caer nin destruirse ninguna cosa della ${ }^{3}$.

Dicha actuación se encontraba en perfecta sintonía con el Fuero Real donde se intentaba preservar el paisaje monumental heredado al afirmarse que ninguno non sea osado de tomar pilares nin columnas nin otras piedras (...) para fazer delas otra labor, tal como ha estudiado la doctora Pérez Monzón ${ }^{4}$.

En la primera mitad del siglo XIV don Juan Manuel, nieto de Fernando III, nos brinda un documento excepcional al detenerse en la mezquita aljama de Córdoba. En sus famosos cuentos de El Conde Lucanor, escritos hacia 1340, nos habla del prestigio que adquirían los hombres por su participación en la construcción de grandes obras de arquitectura. Lucanor, el protagonista del mencionado libro, o mejor dicho el propio escritor que se enmascara en sus personajes, en el cuento XLI, muestra su disgusto porque no le reconocían los avances que había introducido en el arte de la cetrería. Al escuchar las quejas, su criado Patronio le relata una historia del rey de Córdoba Al-Hakam II quien introdujo avances en el instrumento musical del "albogón", o flauta de siete agujeros. Todos se reían de él por ello hasta que amplió la gran mezquita cordobesa, momento a partir del cual fue loado por la maravilla de la construcción (fig. 1):

Et desque él (Al-Hakam) esto oyo (críticas), tomo ende grand pesar, pero commo era muy buen rey, non quiso fazer mal en los que dizian esta palabra, mas puso en su coraçon de fazer otro annadimiento de que por fuerça oviessen las gentes a loar el su

\footnotetext{
${ }^{3}$ Nieto 1980 , p. 134.

${ }^{4}$ Pérez 2012.
} 
fecho. Entonçe, por que la mezquita de Cordoba non era acabada, annadio en ella aquel rey toda la labor que y menguava et acabola. Esta es la mayor et mas conplida et mas noble mezquita que los moros avian en Espanna et loado a Dios, es agora eglesia et llaman la Sancta Maria de Cordova, et offreciola el Sancto rey don Fernando a Sancta María quando gano a Cordova de los moros. Et desque aquel rey ovo acabada la mezquita et fecho aquel tan buen annadimiento, dixo que pues fasta entonçe lo loavan escarniçiendo lo del annadimiento que fiziera en el albogón, que tenia que de alli adellante lo avian a loar con razon del annadimiento que fiziera en la mezquita de Cordova. Et fue depues muy loado. Et el loamiento que fasta entonçe le fazian escaniçiendo lo, finco despues por loor; et oy en dia dizen los moros quando quieren loar algun fecho: "Este es el annadimiento de Alhaquem"5.

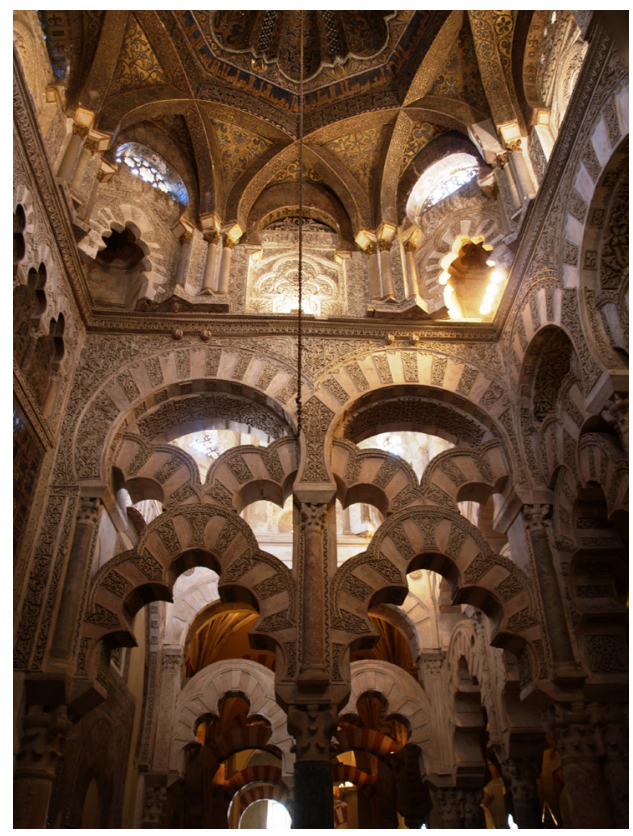

Fig. 1. Macsura de la Mezquita de Córdoba, s. X. Foto del autor.

Siguen resultando sorprendentes las reflexiones que se extraen de dicho texto de don Juan Manuel ante la conciencia que existía en la primera mitad del siglo XIV de que la mezquita de Córdoba era fruto de varias etapas constructivas, y de ellas sobresalía la de Al-Hakam II.

\footnotetext{
${ }^{5}$ Don Juan Manuel, El conde Lucanor, pp. 325-326.
} 
Pasaron los años y el arte de al-Andalus traspasó sus fronteras políticas para convertirse en una posibilidad artística más en los territorios de la Corona de Castilla y León. Hubo diferentes grados de emulación de la arquitectura andalusí, desde las formas a sus espacios entre los siglos IX y XVI, y como éstos, no viajaron necesariamente juntos ${ }^{6}$.

A la segunda década del siglo XVI pertenece la preciosa provisión de Juana I de Castilla en la que se expresa la razón última que nos explica la conservación decidida de la Alhambra y su memoria:

Bien sabeis como por la gracia de Dios nuestro señor e con su ayuda el rey mi señor e padre e la reyna my señora madre que haya santa gloria ganaron la cibdad de Granada e Alhambra della donde está la Casa Real que es tan suntuoso y exçelente edefiçio e la voluntad de los dichos Reyes mis señores e mia siempre ha sido e es que la dicha Alhambra e Casa esté muy bien reparada e se sostenga porque quede para siempre perpetua memoria e porque esto se pueda façer he acordado de le dar e señalar algunas rentas para que con ellas e con lo que mas mandáremos librar la dicha Alhambra e edefiçios della estén bien reparados e no se consuma e pierda tan eçelente memoria e suntuoso edefiçio como es (...) lo cual se ha de haçer gastar en el reparo de los muros e torres e en las casas reales e otras casas e edefiçios de la dicha Alhambra? ${ }^{7}$.

El célebre documento anterior expone y aclara el porqué del aprecio y la responsabilidad que los monarcas castellanoleoneses de la Baja Edad Media mostraron por conservar la memoria de la historia pasada a través de sus testigos monumentales. Pero no cualquier memoria; como veremos en este trabajo, se trataba de su propia memoria capaz de generar sentimientos de pertenencia. ¿Dónde se encuentra la clave de todo ello, de algo tan excepcional y diferente a lo que vemos en otras coronas peninsulares o en otras regiones de Europa? Ya no lo dudamos, todo fue posible gracias al arzobispo Rodrigo Jiménez de Rada y al significado que alcanzó la dimensión cultural de Toledo en su proyecto.

\section{3. ¿DE DÓNDE PARTIMOS? ASPECTOS ARTÍSTICOS COINCIDENTES EN LA CONSTRUCCIÓN DE IDENTIDADES. CÓRDOBA, ASTURIAS Y SEVILLA: SIGLOS VIII-XII}

Es necesario entender el contexto del cual parte Jiménez de Rada para poder comprender su intención en las crónicas que él realiza y en el

\footnotetext{
${ }^{6}$ Ruiz 2004, 2014.

${ }^{7}$ Provisión de la reina D. ${ }^{a}$ Juana hecha en Segovia a 13 de septiembre de 1515, publicada por Gómez-Moreno 1892, pp. 27-28.
} 
papel que juega el paisaje monumental en la creación de identidades. No deberíamos ver ambos factores de manera disociada pues el paso de un texto escrito a un espacio arquitectónico nos habla de audiencias que crecen exponencialmente y de la veracidad, o mejor dicho viabilidad, del mensaje escrito. Es obligado realizar un rápido recorrido por la Córdoba omeya, el reino de Asturias y la Sevilla almohade, antes de desembarcar en el Toledo del primer tercio del siglo XIII.

Las realizaciones omeyas (ss. VIII-X) y almohades (s. XII) aluden a los dos imperios islámicos que se desarrollaron en Occidente y cuyas capitales se hallaban en Europa. Ambos utilizaron de forma deliberada el pasado romano y visigodo de la Hispania tardoantigua y su propia tradición islámicoandalusí al necesitar marcar su identidad y su independencia político-cultural dentro del contexto histórico del Islam al que pertenecen. Entre los textos más preciosos que podríamos recordar se encuentran el sinfín de noticias recogidas en la denominada Crónica del Moro Rasis (ss. IX-X), cuya versión castellana se hace hacia 1300. En la descripción de los diferentes lugares de España se detiene una y otra vez en valorar las huellas arquitectónicas del pasado antiguo en los edificios, en sus técnicas y en sus materiales. Nos interesa especialmente esta crónica pues el texto en castellano de la misma se fija entre los siglos XIII y XIV, periodo en el que arranca la definición de la identidad de la corona castellanoleonesa y en buena medida la de la España posterior. Queremos llamar la atención sobre la mención que se hace de Mérida, de sus piedras mármoles escritas en escuro latín y cómo fueron extraídas de su lugar de origen para afeytar con ellas nuevas obras omeyas ${ }^{8}$.

En este texto se explica a la perfección la existencia de un pasado histórico importante y superior al presente, cuyo material constructivo encarna su identidad perdida. El valor de dicho material será introducido en nuevas edificaciones a las que dota de belleza y dignidad, incluso se habla de un latín antiguo que ya no se entiende.

Los múltiples estudios de la profesora Calvo Capilla abren, diversifican y enriquecen el mensaje político de las grandes empresas constructivas de los omeyas hispanos al reflexionar sobre la ciudad palatina de Madinat al-Zahra y la mezquita aljama de Córdoba. Obras en las que se miraba a Constantinopla, tal como hicieron los primeros califas omeyas de Damasco', pero en las que igualmente se reivindicaba la Hispania romana y visigoda a través de la reutilización de su material de acarreo ${ }^{10}$. Antonio Peña ya demostró hace años que parte del material más precioso de la ampliación de la Mezquita de Córdoba

\footnotetext{
${ }^{8}$ Crónica del Moro Rasis, pp. 73-74; cf. Calvo 2012, p. 133.

${ }^{9}$ Calvo 2008.

${ }^{10}$ Calvo 2012, 2014.
} 
realizada en el siglo IX procedía directamente de la no tan próxima Mérida, y más cuando en la propia ciudad del Guadalquivir eran numerosos los edificios y yacimientos en los que se podía encontrar material romano y visigodo de primera calidad $^{11}$. Ha sido muy habitual interpretar los proyectos omeyas de Córdoba a la sombra, más que en paralelo, de los proyectos expansionistas de los fatimíes en el norte de África. Por el contrario, Calvo Capilla habla de continuidad y con doble fundamento: imitar el comportamiento de los omeyas de Damasco por una parte y, por otra, reivindicar el pasado antiguo hispano ${ }^{12}$.

Lo sorprendente es observar que en el siglo IX en Córdoba, en Asturias $^{13}$ o en Aquisgrán, se estaba procediendo de similar manera, al tomar material antiguo para exponerlo en construcciones emblemáticas construidas por los gobernantes respectivos en ese momento. Carlomagno mira a Rávena, continuadora natural de Roma, en cambio Alfonso II y los siguientes reyes astures, así como los omeyas de Córdoba, buscaron y encontraron su referencia e identidad en la Hispania romana y visigoda, al no dudar en incorporar en sus empresas más importantes lejanos spolia procedentes de edificios hispanos, romanos y visigodos. Proceso común en el occidente tardoantiguo que lucha por reivindicar la vigencia de un orden, ya perdido, del que se consideran herederos, independientemente de su fe religiosa. Existió una mirada y un planteamiento compartido y claramente comprensible ${ }^{14}$.

¿Y qué sucede en la Sevilla almohade? Tras la caída del Califato de Córdoba y la disolución de los reinos de taifas ante la invasión almorávide a lo largo de las últimas décadas del siglo XI, podemos decir que solo el Imperio Almohade volvió a tener unas posibilidades reales de crear un nuevo imperio islámico en occidente, capaz de unir de nuevo las dos orillas del Estrecho de Gibraltar, y del que Sevilla llegará a ser su capital europea entre los últimos años del siglo XII y primeros del XIII ${ }^{15}$. Una vez más parece que en lo político se necesita volver al pasado histórico peninsular. Su edificación más importante conservada es el alminar de la mezquita aljama hispalense erigida a finales del siglo XII: la Giralda. Su observación no está exenta de sorpresas. En ella se repasan, paso a paso, los momentos históricos más sobresalientes del pasado. En su base todavía se contempla un importante conjunto de piezas romanas, aras o pedestales, y según ascendemos en altura el material romano se conjuga con el visigodo y el omeya ${ }^{16}$. Casi dos siglos más tarde asistimos

\footnotetext{
${ }^{11}$ Peña 2010.

${ }^{12}$ Calvo 2008, 2014.

${ }^{13}$ Bango 1985, 2008.

${ }^{14}$ Ruiz 2014.

${ }^{15}$ Sobre el periodo almohade: Buresi, et al. 2014.

${ }^{16}$ Jiménez 1998, p. 39.
} 
a la misma exposición histórico-secuencial, en esta ocasión por parte del rey de Castilla y León Pedro I en el Palacio de la Montería, construido en el tercer cuarto del siglo XIV ${ }^{17}$. No se trata de nada nuevo, la acrópolis de Atenas expuso (s. V a. C.) las ruinas de sus propios templos destruidos en las guerras médicas para que su visión intencionada se convirtiera en un acitate moral desde el ágora, corazón político de la ciudad. Su recuerdo era un mensaje de esperanza en la victoria final sobre los persas, para que esta redundase de forma perpetua en la construcción de su identidad, tal como hoy seguimos observando ${ }^{18}$.

Al-Andalus y la Corona de Castilla y León siempre vieron con claridad la importancia de reivindicar el pasado histórico como fuente de legitimidad y, por supuesto, de identidad. A partir de la inercia existente aludida en estas líneas, Rodrigo Jiménez de Rada primero y Alfonso X después comprendieron con claridad la necesidad de incorporar la Hispania antigua y tardoantigua, así como al-Andalus, en la configuración de un proyecto político que gozaría de un enorme futuro ${ }^{19}$. A partir de ahora veremos cómo Jiménez de Rada materializó su proyecto, el cual marcará el arranque del scriptorium alfonsí.

\section{CUANDO EL ÁRABE Y LA CULTURA VISUAL ARABIZADA}

SE CONVIERTEN EN SEÑAL DE IDENTIDAD CRISTIANA: RODRIGO JIMÉNEZ DE RADA y SAN ROMÁN DE TOLEDO. SINERGIAS ARTÍSTICAS ENTRE TOLETUM Y ROMA

Etiam in isto medio fuit apud Hispalim gloriosus et sanctissimus Ihoannes episcopus, qui ab Arabibus Çayet Almatran uocabatur, et magna sciencia in lingua Arabica claruit, multis miraculorum operationibus gloriosus efulsit, qui etiam sacras Scripturas catholicis expositionibus declarauit, quas ad informationem posterorum arabice conscriptas reliquit ${ }^{20}$.

Con estas palabras Rodrigo Jiménez de Rada ensalzaba la sabiduría del obispo Juan de Sevilla (siglo IX), quien gracias a su conocimiento del árabe pudo traducir las Sagradas Escrituras a dicha lengua según la ortodoxia católica. Aunque automáticamente se haga una conexión ideológica entre el árabe y la religión islámica, evidentemente no debemos cometer ese error. No olvidemos que el conocimiento de esta lengua por parte de un cristiano en la Baja Edad Media hispana significaba que muy posiblemente podía provenir de una familia cristiana muy, muy antigua, cuyos orígenes cristianos se podrían

\footnotetext{
${ }^{17}$ Ruiz 2014.

${ }^{18}$ Véase Schattner, Valdés 2009.

${ }^{19}$ Ruiz 2014.

${ }^{20}$ Jiménez de Rada, Historia de Rebvs Hispanie, p. 118.
} 
remontar a fechas anteriores a la propia llegada de los musulmanes y al inicio del cristianismo hispanorromano en la ciudad. Hablamos de la población mozárabe que con tanto celo preservó sus creencias y sus ritos durante los siglos de vida de al-Andalus. Circunstancia que en Toledo alcanzó un protagonismo destacado y singular en comparación con otros lugares.

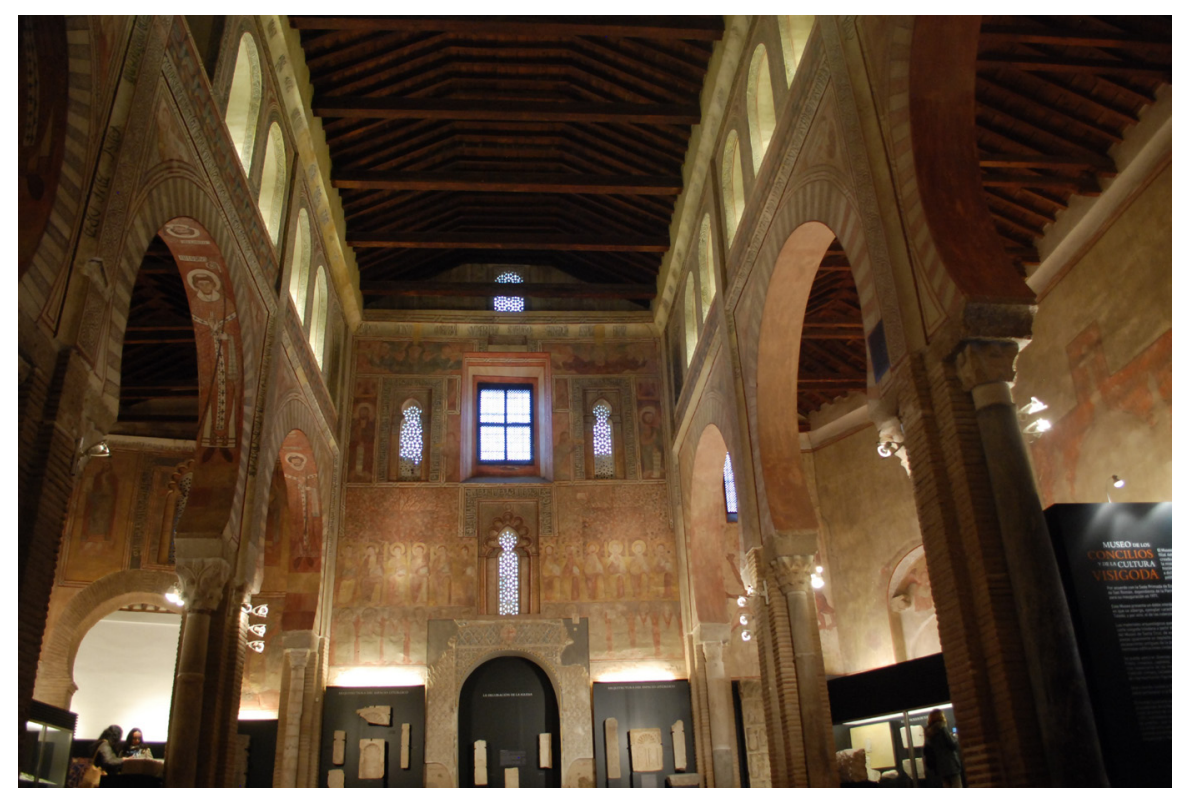

Fig. 2. San Román de Toledo. 1221. Foto del autor.

En la iglesia de San Román de Toledo (fig. 2), realizada en el primer cuarto del siglo XIII y consagrada en 1221 por Rodrigo Jiménez de Rada, se despliega todo un plan ideológico donde el pasado es reivindicado en aras de allanar los caminos del futuro ${ }^{21}$. En dicha iglesia parece aludirse al conflicto de la sociedad cristiana de la ciudad, pues a través de su fábrica y pinturas se reivindica la unión, tal vez mejor dicho convivencia, de las dos iglesias cristianas vigentes, y en ocasiones rivales, de Toledo: la de rito romano o francés, impuesta en el siglo XI tras la conquista de la ciudad de manos de la monarquía, y la de rito hispano, también conocido como visigodo o toledano, de origen preislámico y por lo tanto visigodo o hispanorromano. En la propia

${ }^{21}$ Queremos dar las gracias a la profesora Jerrilynn Dodds, pues ella nos hizo entender hace más de una década el carácter especial de este templo y la necesidad de estudiar a Jiménez de Rada. Véase Dodds 2007; Abad 2004, como puntos de partida para el estudio del edificio. 
crónica de Jiménez de Rada, La Historia de Rebus Hispanie, estudiamos cómo el propio arzobispo se lamenta de la pérdida del rito hispano tras la conquista de la ciudad por Alfonso VI ${ }^{22}$. En la basílica de San Román se realiza un homenaje evidente a la comunidad mozárabe y se alude a la existencia de los dos ritos. En ella se utiliza material de acarreo romano y visigodo junto a la construcción de grandes arcos de herradura que han inducido continuamente, según nuestro punto de vista, a un posible error interpretativo. Desde nuestro análisis, algunos detalles decorativos nos han distraído del sentido general del proyecto. Ciertamente, la alternancia de dovelas decoradas y lisas de los grandes arcos, la utilización de una cenefa entrelazada que perfila la rosca de los grandes arcos y formaliza el alfiz que los encuadra, o la existencia de arquillos polilobulados con dovelas alternas en rojo y blanco son detalles que lógicamente remiten al paisaje monumental andalusí de la ciudad, como ya explicó Jerrilynn Dodds ${ }^{23}$.

A pesar de dichos detalles de recuerdo andalusí, lo más llamativo para nosotros es la disposición de las dovelas pintadas que decoran el frente de los grandes arcos. Estas muestran un despiece radial desde el salmer o la línea de imposta (fig. 3) ${ }^{24}$, tal como son los arcos de herradura preislámicos, en evidente alusión a los orígenes tardorromanos cristianos de la ciudad al igual que las piezas de spolia que comentaremos más abajo. Pintura que no alude a la técnica real constructiva del enjarjado ${ }^{25}$ al quedar esta oculta, es decir, con un despiece constructivo donde los ladrillos se disponen de manera horizontal y paralelos al suelo hasta la altura del riñón del arco. Por lo tanto, la pintura esconde claramente cómo están hechos. Existe una intencionalidad muy clara de que su imagen visual sea distinta a la que, por ejemplo, vemos en los arcos de un edificio islámico clásico omeya, taifa o almohade, en donde el despiece de sus dovelas por debajo del riñón del arco, o bien no aparece en la decoración, o cuando lo hace muestran un despiece de dovelas oblicuo, y nada radial, por lo tanto muy distinto $^{26}$. En San Román los grandes arcos de herradura que definen las tres naves de la basílica apean en unos pilares rectangulares en cuyos frentes se exhibe un

22 Jiménez de Rada, Historia de Rebvs Hispanie, pp. 207-209.

${ }^{23}$ Dodds 2007, pp. 220-226.

${ }^{24}$ A diferencia de los arcos omeyas donde se observa de forma evidente que son enjarjados, es decir, que sus dovelas desde la imposta hasta la altura de sus riñones se disponen en paralelo al suelo, lo cual les dota de mayor estabilidad y posibilita mayor peralte y cierre de su luz.

${ }^{25}$ Cualidad que sí fue habitual en los arcos de herradura islámicos. Sigue siendo un clásico Gómez Moreno 1906.

${ }^{26}$ Compárense, por ejemplo, los arcos de San Román con el de embocadura del mihrab de la Aljafería de Zaragoza. Ciertamente la utilización de dicha técnica hace posible la construcción de arcos de herradura con un gran peralte que recuerda en parte al que presentan los omeyas, taifas o almohades, pero como se ha mencionado se quiere marcar otra intención gracias al despiece pintado. 
riquísimo material de acarreo romano y visigodo, en sintonía con los arcos aludidos. Es necesario recordar la dimensión política de la reutilización deliberada de material antiguo spolia en obras arquitectónicas de primer orden. La utilización de material constructivo seleccionado del pasado, con sentido intencionado (político, legitimador, económico, etc.) ha sido una práctica común a lo largo de la historia con un sentido reivindicativo más que evidente ${ }^{27}$.

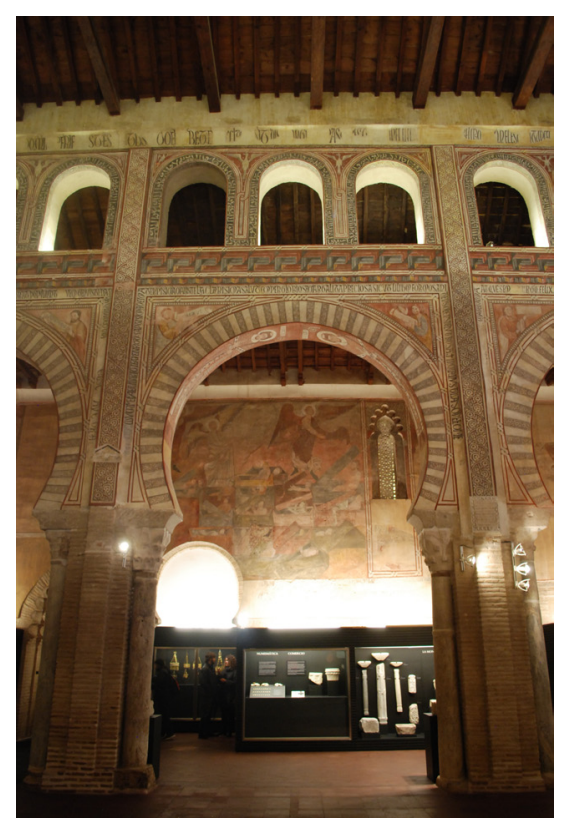

Fig. 3. San Roman de Toledo. 1221. Foto del autor.

Por todo lo explicado, para nosotros los grandes arcos de San Román ni son islámicos ni pretenden su recuerdo, y menos aún pueden vincularse con la imagen de mezquita alguna. Pensamos que su intencionalidad es claramente el recuerdo de una basílica tardorromana o visigoda, y arabizada, como era la población mozárabe: población cristiana de origen tardoantiguo-visigodo que se fue paulatinamente arabizando entre los siglos VIII y XI.

En las pinturas de San Román, fruto de una misma campaña y coetáneas a la arquitectura de la iglesia, observamos la combinación de inscripciones

${ }^{27}$ Ruiz 2014, a partir de los trabajos de D. Kinney, C. Rudolph, P. Liverani, B. Brenk, J. Elsner, F.A. Bauer, o de C. Ewert e I. Bango, entre otros. 
en latín y en árabe ${ }^{28}$. Las primeras aluden especialmente al salmo $103^{29}$, mientras que las segundas repiten continuamente la expresión al-yumn wa l- 'iqbãl o, lo que es lo mismo, "la felicidad y la prosperidad" tal como ha estudiado Juan Antonio Souto ${ }^{30}$. Las pinturas latinas parecen hacer alusión a todo el ambiente religioso toledano de la primera mitad del siglo XIII y por supuesto al mundo mozárabe y su liturgia ${ }^{31}$.

Como ya hemos recordado en el inicio de este apartado, el árabe es la lengua de los cristianos (mozárabes) que mantuvieron el rito hispano bajo la dominación musulmana de la ciudad entre los siglos VIII y XI y como es lógico dicha comunidad se fue paulatinamente arabizando a lo largo de los cuatro siglos de dominación política islámica ${ }^{32}$. El latín, tras la llegada de Alfonso VI a la ciudad en 1086, pasó a convertirse en la expresión única del rito romano reformado impulsado por la monarquía y por los monjes cluniacenses como signo de europeización de los reinos hispanos, lo cual marcó una difícil frontera con la antigua liturgia hispana de los mozárabes, donde la lengua árabe era habitual ${ }^{33}$.

En el mismo templo toledano hallamos combinados a los padres de la iglesia hispana (San Isidoro o San Leandro), con aquellos que se identifican con la reforma romana y sus raíces (San Ambrosio, San Benito, San Gregorio o San Bernardo) (fig. 4). Pocos edificios hay en España donde la utilización de spolia llegue a tener tanto protagonismo, con tantos fustes de columnas, capiteles, cimacios y otras piezas arquitectónicas. Algunas de ellas torpemente puestas para llamar la atención, y más cuando la arquitectura general del edificio es bastante cuidada.

Los mozárabes de Toledo irían perdiendo el árabe con el paso de los siglos pero todavía en el siglo XVI había familias que lo mantuvieron en su rúbrica ${ }^{34}$. En este contexto creemos que deben comprenderse las inscripciones en árabe de otras iglesias toledanas, caso por ejemplo de las que aún se conservan en la ermita del Cristo de la Luz.

${ }^{28}$ Rallo 2002, pp. 277-279.

${ }^{29}$ Actualmente Salmo 104. Véase especialmente el capítulo II del estudio realizado por el Grupo Ailbe, en la revista on line Círculo del Románico en febrero de 2011 (Grupo Ailbe 2011), partiendo de los trabajos de Germán Prado O.S.B. (Prado 1928). Se habla especialmente de la importancia de la liturgia mozárabe relacionada con la festividad de Pentecostés.

${ }^{30}$ Souto 2011.

${ }^{31}$ Dodds 2007, pp. 224-242, hace una lectura de las pinturas en relación con el discurso del Apocalipsis presente en el programa pictórico y su importancia en la iglesia toledana dentro del contexto histórico de la guerra contra el imperio almohade, en la que la batalla de las Navas de Tolosa impulsada por Jiménez de Rada fue esencial.

${ }^{32}$ Sobre la comunidad mozárabe es obligado Aillet 2010.

${ }^{33}$ Rubio 2006.

${ }^{34}$ González 1930 observa cómo se explica frecuentemente en la documentación que las partes de un acuerdo entienden perfectamente el árabe. 


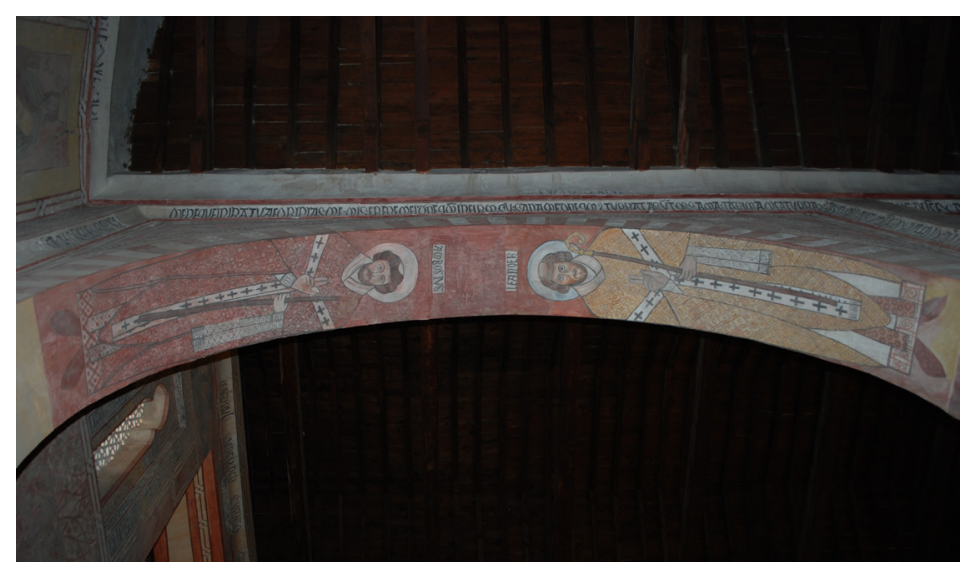

Fig. 4. San Román. Detalle de San Ambrosio y San Leandro. 1221. Foto del autor.

Roma puede completar perfectamente la lectura del edificio. Jiménez de Rada estuvo en varias ocasiones allí y tuvo una participación más que destacada en el célebre IV concilio de Letrán de 1215 donde se hizo toda una declaración de intenciones respecto a la expansión e implantación de la iglesia gregoriana reformada de Roma ${ }^{35}$. El proyecto de San Román participa de ese ambiente y viene a marcar el paso del pasado al futuro, pero sin denostar la tradición toledana antigua a la que se hace un sentido homenaje. Ya no debe verse con recelo y desconfianza a aquella iglesia que se mantuvo firme durante el período político islámico de la ciudad, que llegó a ser acusada de heterodoxia por el tema del adopcionismo. Bien sabía Jiménez de Rada que si en su proyecto de lograr la sanción papal para que le devolviera a Toledo la primacía entre las diócesis hispanas ${ }^{36}$, tal como fue en época visigoda, debía primero solucionar el tema de la división de las dos sensibilidades cristianas de su diócesis: la mozárabe y la romana. Diego Gelmírez un siglo antes acudió a Roma para lograr que su diócesis fuese metropolitana al contar con cuerpo apostólico ${ }^{37}$, así como otros monarcas hispanos también tuvieron el horizonte romano en sus construcciones ${ }^{38}$. En Roma el arzobispo toledano pudo ver basílicas de origen tardoantiguo y altomedieval que muy bien pueden recordarnos en muchos aspectos a San Román (utilización de spolia, utilización de arquerías en la definición de naves, armaduras de madera como

\footnotetext{
${ }^{35}$ Gorosterratzu 1925, pp. 144-159.

${ }^{36}$ Ibidem.

${ }^{37}$ Castiñeiras 2010.

${ }^{38}$ Queremos agradecer los comentarios de la profesora y amiga Marta Poza Yagüe. Sobre la presencia de Roma y su mensaje en el Aragón altomedieval véase Martínez de Aguirre 2011; Poza 2014; García 2018.
} 
sistema de cubierta). Todavía hoy podemos observar los ejemplos de San Lorenzo Extramuros, San Pablo Extramuros o Santa Sabina. Es decir, en San Román vemos muchas posibles intenciones que al final explican su carácter único y excepcional. Resulta llamativa la gran imposta pictórica que divide las arquerías en dos cuerpos. Se trata de dos ricas cenefas de intensos colores que simulan un gran relieve como si de un entablamento se tratase. La inferior consiste en una cinta de paralelogramos adyacentes, polícromos, y con efecto tridimensional, mientras que la superior es una banda de meandros en L cuadrados, polícromos y con igual sensación de relieve. Dichos detalles se pueden ver en la pintura de 1200 pero fue igualmente habitual en la pintura y en los mosaicos tardoantiguos ${ }^{39}$. Las rarezas de una fábrica que ha llevado a ser puesta en relación con la imagen de lejanas mezquitas, cuando lo que debemos ver en ella es una basílica tardoantigua, como serían las de Toledo o las aún conservadas de Roma. Difícilmente puede pensarse que se hubiera conservado más allá del recuerdo ninguna de las grandes basílicas visigodas toledanas en tiempos de Jiménez de Rada.

San Román es la lección legitimadora de las pretensiones político-religiosas de Jiménez de Rada, mientras que la catedral gótica, iniciada en 1226, es el gran proyecto de futuro tanto de la iglesia toledana como de la propia monarquía castellana que la tomará como lugar de enterramiento y de reconocimiento. Catedral que vino a ser en el siglo XIII la construcción más revolucionaria del paisaje monumental de todo el centro peninsular pues nada había en él que pudiera compararse a semejante proyecto de cinco naves y doble girola. Desde luego, en la gigantesca diócesis de Toledo ningún edificio se aproximaba en nada a ella, y sin duda superaba claramente a todos los proyectos iniciados en la península hasta entonces. San Román y la catedral de Toledo son dos eslabones necesariamente unidos en un proyecto perfectamente diseñado, que además contestaba y se oponía a las pretensiones de la diócesis tarraconense por ser también la primada. En Tarragona se apostó en su gran obra catedralicia por un proyecto magnífico en la tradición del tardorrománico. La ubicación y el propio paisaje monumental de la ciudad contaría, tal como hoy sucede, con numerosísimos vestigios de su pasado cristiano-tardorromano, que la dotarían de la legitimidad necesaria ${ }^{40}$. No olvidemos que desde el sínodo de Tarragona de 1241 se llegó a declarar la excomunión de Jiménez de Rada ante sus pretensiones hegemónicas sobre la diócesis de Valencia, tras la conquista de Jaime I de Aragón, al querer hacer valer la primacía de la diócesis toledana ${ }^{41}$. Es decir, continuaba la problemática del pasado sobre de qué diócesis debía ser la primada en los territorios

\footnotetext{
${ }^{39}$ Agradecemos a Alexandra Uscatescu los comentarios sobre este tipo de decoración en la arquitectura tardoantigua. Véase Balmelle, et al. 1985.

${ }^{40}$ Serrano 2018.

${ }^{41}$ Gorosterratzu 1925, pp. 324-328.
} 
hispanos. ¿Estaremos asistiendo además a paisajes monumentales en conflicto entre Toledo y Tarragona? San Román alude a las basílicas tardoantiguas, la catedral toledana a las nuevas formas del norte de París, Le Mans o Bourges, mientras que Tarragona se ubica en el tardorrománico.

Después del IV concilio de Letrán y del gobierno de Jiménez de Rada al frente de la diócesis toledana no podemos decir que se hubiera producido menoscabo alguno respecto a las aspiraciones de los cristianos mozárabes en Toledo, más bien lo contrario ya que encontraremos cómo un miembro destacado de la comunidad mozárabe de Toledo, don Gonzalo Pérez Gudiel, llegará a ser arzobispo de la ciudad entre 1280 y $1298^{42}$.

\section{5. ¿HISPANIA O HISPANIAE ${ }^{43}$ LA HISTORIA DE REBUS HISPANIE, LA HISTORIA ARABUM Y LA RAZÓN DE LA LEY DELLOS}

El profesor Carlos de Ayala recientemente ha introducido un debate esencial como es el de la percepción de Hispania en las fuentes escritas de la Edad Media $^{44}$. Tras hacer un concienzudo balance historiográfico sobre el particular, y al repasar las visiones que se fueron dando en las crónicas medievales desde época visigoda, nos ilustra perfectamente sobre el giro paulatino que culmina en el siglo XIII. La historia de Hispania también puede ser de Hispanie, en plural, al poder entenderse como resultado de una colectividad de pueblos que se sucedieron en el tiempo. Idea de colectividad que el profesor Ayala nos recuerda que pudo proceder de ambientes mozárabes de al-Andalus desde época omeya ${ }^{45}$. Creemos que evidentemente el arte dice lo mismo. Ya hemos visto páginas arriba cómo el concepto de Hispania también se contemplaba al sur de la frontera al estar presente con claridad en al-Andalus. Creemos que dicha premisa queda claramente evidenciada en los trabajos ya aludidos de Susana Calvo referidos a la Córdoba omeya donde hubo una conciencia clara y reflexionada sobre el concepto de Hispania. Igualmente, se vislumbra la misma reflexión ante la reutilización de material de acarreo seleccionado en la Giralda de Sevilla tal como ya se ha señalado.

La lectura de la Historia de Rebus Hispanie y de la Historia Arabum resulta esclarecedora al descubrirnos la intención del arzobispo toledano. En la primera vemos la valoración del buen hacer de reyes y gobernantes, independientemente de su fe religiosa, y en ocasiones se alude a las obras arquitectónicas

\footnotetext{
${ }^{42}$ Linehan, Hernández 2004.

${ }^{43}$ Epígrafe copiado de un trabajo de Carlos de Ayala Martínez quien utiliza el subtítulo ¿Hispania o Hispaniae? Ayala 2017, p. 216. Es muy interesante completar este trabajo con la percepción que existía desde la historia del arte al otro lado de la "frontera", tal como se puede comprobar en: Calvo 2012, 2014.

${ }^{44}$ Ayala 2017.

${ }^{45}$ Ibidem, p. 210.
} 
como un elemento más de las virtudes del monarca, emir o califa comentado. Noticias que ya se utilizaron en el pasado, caso de la presencia de la arquitectura prerrománica en las crónicas asturianas, y que se repetirán y ampliarán en la Estoria de España de Alfonso $\mathrm{X}^{46}$.

La Historia Arabum supone una verdadera revolución respecto a la mirada del pasado. Contamos con el reciente y documentado trabajo de Fernando Bravo López quien acaba de editar y publicar un amplio estudio sobre la mencionada crónica. En él expone de forma clara y con valoración crítica la historiografía existente respecto a la labor cronística de Jiménez de Rada y nos ilustra con claridad nuevas valoraciones muy interesantes al respecto ${ }^{47}$.

En la Historia Arabum Jiménez de Rada no se centra en darnos una visión demoledora y negativa respecto al pasado de la España andalusí y sus críticas, cuando existen, resultan livianas si se comparan con otras fuentes de la época. Como muy bien explica Bravo López no era necesario legitimar lo que ya estaba sobradamente legitimado y hecho ${ }^{48}$. Todo ello podría resultarnos contradictorio y más cuando el propio arzobispo logró de Inocencio III bula de cruzada en la lucha contra el islam, que él mismo promulga en su viaje por Europa de 1211. Al fin y al cabo, de la contradicción surgen los proyectos de futuro. No tiene ningún problema en ensalzar a aquellos gobernantes que él considera buenos e incluso los presenta como un ejemplo a seguir, al igual que a tantos otros cristianos. Bravo López evidencia que el cronista no repite sin más unas noticias tras otras procedentes del pasado, pues elige y también redunda en aquellos aspectos que considera más interesantes, e infravalora otros sobre los que no quiere cargar las tintas. La Historia Arabum viene a completar la Historia de Rebus Hispanie, a la que se alude en no pocas ocasiones para que se vea que todo forma parte de un mismo proyecto. El patrimonio de al-Andalus pasa a ser considerado como uno más, y recibirá los mismos elogios que pudiéramos encontrar respecto a las obras asturianas ramirenses del Monte Naranco. Es muy interesante la reflexión de Bravo López al presentarnos la crónica como texto formativo dirigido a Fernando III para su aprendizaje en el buen gobierno a través de los buenos ejemplos que nos brinda la historia del pasado, como maestra de presente y futuro ${ }^{49}$. Aunque para nosotros el que más bien parece recoger el testigo del Toledano a todos los niveles es el futuro Alfonso X.

${ }^{46}$ Ruiz 2014.

${ }^{47}$ Bravo 2019.

${ }^{48}$ Ibidem, p. 212.

${ }^{49}$ Ibidem, pp. 121-123, 211. Incluso recuerda los trabajos de P. Linehan sobre las excelencias de Al-Hakam I, considerado con la misma maiestas de la que pudiera gozar el mejor de los príncipes cristianos. 
La Historia Arabum adquiere un protagonismo singular en la labor cronística del arzobispo. Respeta continuamente en su relato el cómputo árabe al dar las cronologías y toma las noticias de las crónicas árabes que tuviera al alcance de su mano, si bien no parece que siga una única fuente en particular ${ }^{50}$. Comienza su historia, lógicamente, con Mahoma y con el santuario de la Meca al que no duda en vincular con una iglesia ${ }^{51}$. Una vez en al-Andalus se recuerda cómo Abd al-Rahman I comenzó la gran mezquita de Córdoba que sobrepujase en maravillosa obra a todas las mesquitas de los árabes ${ }^{52}$. Hisam I es ensalzado especialmente por su labor edilicia. Se habla de cómo invirtió parte de las ganancias obtenidas en la guerra para terminar la aljama cordobesa iniciada por su padre, así como de la traída de tierra desde Narbona para construir una mezquita en el interior del alcázar cordobés. El mismo emir construyó muchas mezquitas, renovó las antiguas y se incide en cómo él mismo estuvo en la construcción del nuevo puente de la ciudad ${ }^{53}$. Muy interesante resulta el detalle que se introduce al tratar el gobierno de Al-Hakam I, muy alabado, de quien se dice fue sabio e esforçado en las batallas, e, segunnt lo afirma la razón de la ley dellos, fue bienaventurado ${ }^{54}$. El comentario la razón de la ley dellos es esclarecedor al asumirse la moralidad de la diversidad. De dicho emir, entre sus múltiples cualidades, se valora su capacidad de justicia pues él personalmente judgava a los pobres e buscaba a los mefechores por refrenar a los falsos juezes ${ }^{55}$. En definitiva, se valoran cualidades no necesariamente religiosas de un gobernante virtuoso según su ley. Abd al-Rahman II es recordado por empedrar las plazas de Córdoba y por traer el agua de la sierra por cannos de plomo que afloraría en las fuentes cerca de la mezquita y del alcázar ${ }^{56}$. Es una pena que no se digan más cosas de gobiernos tan importantes como el de Abd al-Rahman III o el de Al-Hakam II. Del primero se dice que adornó la mesquita de Córdova, e otras muchas, e ensanchó las reales obras ${ }^{57}$, mientras que del segundo nada se comenta salvo que guardó el reino por templanza paterna $l^{58}$. Junto a noticias de este tipo luego hay muchas más igualmente interesantes como el saqueo de una ciudad que parece indicar que se trata de Madinat al-Zahra ${ }^{59}$, así como del cementerio real omeya en el

${ }^{50}$ Ibidem, pp. 97-150.

${ }^{51}$ Ibidem, pp. 94-105. Jiménez de Rada, Estoria de los Arabes, pp. 257-268.

52 Jiménez de Rada, Estoria de los Arabes, pp. 257-268.

${ }^{53}$ Ibidem, pp. 306-307.

${ }^{54}$ Ibidem, p. 309.

${ }^{55}$ Ibidem.

${ }^{56}$ Ibidem, p. 319.

${ }^{57}$ Ibidem, p. 328.

${ }^{58}$ Ibidem.

${ }^{59} \mathrm{Ibidem}$, pp. 337-338. Matthias Maser interpreta con toda lógica que Açafrán se corresponde con Madinat al-Zahra (Maser 2006, p. 344). 
interior del alcázar de Córdoba ${ }^{60}$, etc. Es evidente que no vamos a encontrar datos nuevos o espectaculares, pero lo realmente sobresaliente es la intención de hacer una historia de al-Andalus, entendido este como parte de Hispania.

Tras la ingente labor de Rodrigo Jiménez de Rada el siguiente y definitivo paso lo protagonizará el rey Sabio. El scriptorium de Alfonso X elabora en el tercer cuarto del siglo XIII la Estoria de España en donde se recogen, en orden cronológico, noticias de la España pagana, cristiana, hebrea o andalusí ${ }^{61}$. Estoria que se inicia en Sevilla con la llegada de Hércules y finaliza en la misma ciudad con la llegada a la misma de Fernando III. En ella se repiten múltiples noticias recogidas en las crónicas de Jiménez de Rada, caso del inicio de la arabización de la España tardoantigua al escribir que el obispo hispalense Juan, al poco tiempo de llegar los musulmanes, tradujo al árabe las sagradas escrituras, tal como ya vimos ${ }^{62}$. En la crónica alfonsí, y sin entrar ahora en la problemática de su elaboración y terminación ${ }^{63}$, lo realmente novedoso es encontrar en un mismo discurso muy bien hilado la alabanza a la labor arquitectónica de los romanos, de los reyes visigodos (Leovigildo, Sisebuto o Bamba), de los monarcas asturianos (Alfonso II o Ramiro I) o de los emires cordobeses. Es decir, no se excluye nada ni a nadie, y equiparar a un mismo nivel de documento histórico las realizaciones prerromanas, romanas, visigodas, omeyas, asturianas o almohades supone un salto cualitativo de enormes consecuencias. Si un discurso religioso presenta las reliquias como fundamento último e incontestable de sus creencias, los edificios conservados serán concebidos de igual manera para otorgar la veracidad necesaria y visible del discurso cronístico. La torre de Hércules de la Coruña, el puente romano de Alcántara (Cáceres), las murallas visigodas de Toledo, la Mezquita de Córdoba, las obras ramirenses en el Monte Naranco de Oviedo, la catedral de Santiago de Compostela, la Giralda de Sevilla o el monasterio de las Huelgas de Burgos fueron evocados en las crónicas alfonsíes a nivel de igualdad, pues en ellos residía la diversidad y la veracidad de su Estoria de España, de ahí que se preservase materialmente de forma consciente su memoria ${ }^{64}$. Todo indica que aquello que sucedió en Hispania/España puede y debe contarse y salvarse, como si de un salvoconducto se tratase para poder pasar al futuro.

En definitiva, podemos afirmar que se copia, se continúa y se completa en un relato único la labor ideológica iniciada en las crónicas elaboradas en el scriptorium toledano auspiciado por don Rodrigo.

\footnotetext{
${ }^{60}$ Jiménez de Rada, Estoria de los Arabes, p. 341.

${ }^{61}$ Ruiz 2014.

${ }^{62}$ Primera Crónica General de España, p. 326.

${ }^{63}$ Fernández-Ordóñez 2000.

${ }^{64}$ Ruiz 2014.
} 


\section{EL INICIO DE UN NUEVO COMPORTAMIENTO EN LA ASUNCIÓN DEL ARTE ANDALUSÍ: BRIHUEGA Y TOLEDO}

Como hemos repetido en tantas ocasiones, con Jiménez de Rada comenzó la historiografía laudatoria del más importante edificio islámico de Occidente y Europa: la Mezquita de Córdoba de la que se dice quae cunctas Mesquitas Arabum ornatu et magnitudine superabat ${ }^{65}$. Con estas contundentes palabras el arzobispo toledano señalaba en su Historia de Rebvs Hispaniae las excelencias del edificio. Se puede considerar el inicio de un nuevo comportamiento hacia el patrimonio de al-Andalus que se podrá asumir y comprender sin problemas, así como su emulación y copia en nuevas obras.

Tras el armazón teórico que hemos observado en las crónicas del arzobispo es necesario dar un paso más y ver hasta qué punto la teoría fue llevada a la práctica. Nos centraremos en dos aspectos que consideramos muy esclarecedores en el punto de arranque hacia una nueva consideración del arte andalusí en la corona castellanoleonesa. Hubo elementos omeyas puntuales que tuvieron su eco en la arquitectura astur, leonesa y castellana entre los siglos IX y XII ${ }^{66}$. En el siglo XIII vemos que todo el discurso teórico se enriquece y de nuevo Toledo centrará nuestra mirada. Nada diremos de las artes suntuarias pues la propia riqueza de su materialidad les permitió tener vida propia al formar parte del consumo del lujo. Tesoros como el de San Isidoro de León, o ajuares funerarios de la entidad que presenta el del propio Rodrigo Jiménez de Rada en su enterramiento de Santa María de Huerta son suficientemente elocuentes. En ellos se custodian ricas piezas, ricas telas, de orígenes múltiples: de la Hispania andalusí y cristiana, de Francia, del norte de Europa, de Inglaterra o del Mediterráneo oriental bizantino o fatimír ${ }^{67}$.

Hay dos aspectos del arte procedente de al-Andalus que nunca perdieron el recuerdo de su origen, nos referimos a la pintura mural conocida como pintura "de lo morisco" o de "echar cintas" y a las cúpulas de mocárabes. Carmen Rallo Gruss nos habla del carácter andalusí de este tipo de pintura en técnica y diseño ${ }^{68}$. Es la típica pintura a la almagra de decoración de lazo donde las cintas de color rojo se entrelazan en ricas composiciones

${ }^{65}$ Jiménez de Rada, Historia de Rebvs Hispanie, p. 299.

${ }^{66}$ Ruiz 2004.

${ }^{67}$ Queremos ensalzar muy especialmente la visión del libro de reciente aparición El Mediterráneo y la internacionalización de la producción textil medieval (Rodríguez, García 2019), especialmente el artículo de Rodríguez Peinado en donde se introduce en varios conjuntos como el de San Isidoro de León (Rodríguez 2019, pp. 32-39). Sobre el ajuar de Jiménez de Rada en Santa María de Huerta sigue siendo obligada, Mantilla de los Ríos 1995.

${ }^{68}$ Rallo 1998. 
geométricas. En Toledo hay bellísimos ejemplos de época omeya y taifa ${ }^{69}$. De época cristiana debemos recordar algunos ejemplos de la primera mitad del siglo XIII. Comenzaremos con el zócalo conservado en el Museo de Santa Cruz procedente de las casas sobre las que se construyó la sinagoga de Santa María la Blanca datado en la primera mitad del siglo $\mathrm{XIII}^{70}$. Especialmente interesante es el pequeño fragmento que ha llegado hasta nosotros de una decoración exterior de un vano ciego del primer cuerpo del ábside del Cristo de la Vega cuya cronología se considera del siglo XIII y anterior a 1250 (figs. 5 y 6) ) $^{71}$. Dicha decoración cambia por completo la imagen que tenemos actualmente de la arquitectura toledana realizada en ladrillo, cuyos paramentos suelen aparecer hoy descarnados sin su piel pictórica protectora.

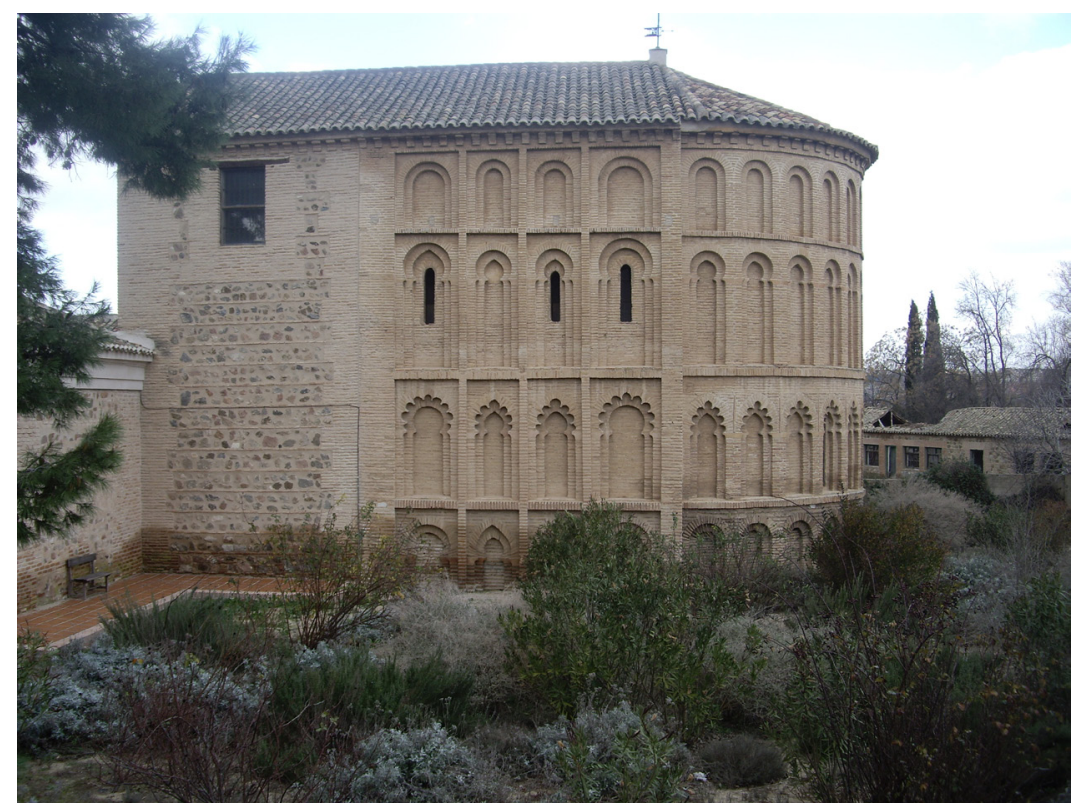

Fig. 5. Ermita del Cristo de la Vega de Toledo. Primera mitad del siglo XIII. Foto del autor.

${ }^{69}$ Entre otros pueden recordarse los zócalos conservados en la conocida casa toledana de la calle Locun con la plaza Abdón de Paz. Más sencillos son los zócalos de la Casa del Temple (Calle Soledad) y del palacio cuyos restos pueden visitarse en el exconvento de Santa Fe.

${ }^{70}$ Rallo 2002, pp. 277-279.

${ }^{71}$ Pérez 1992, p. 206. Véase también Abad 1991, vol. II, pp. 232-238. 


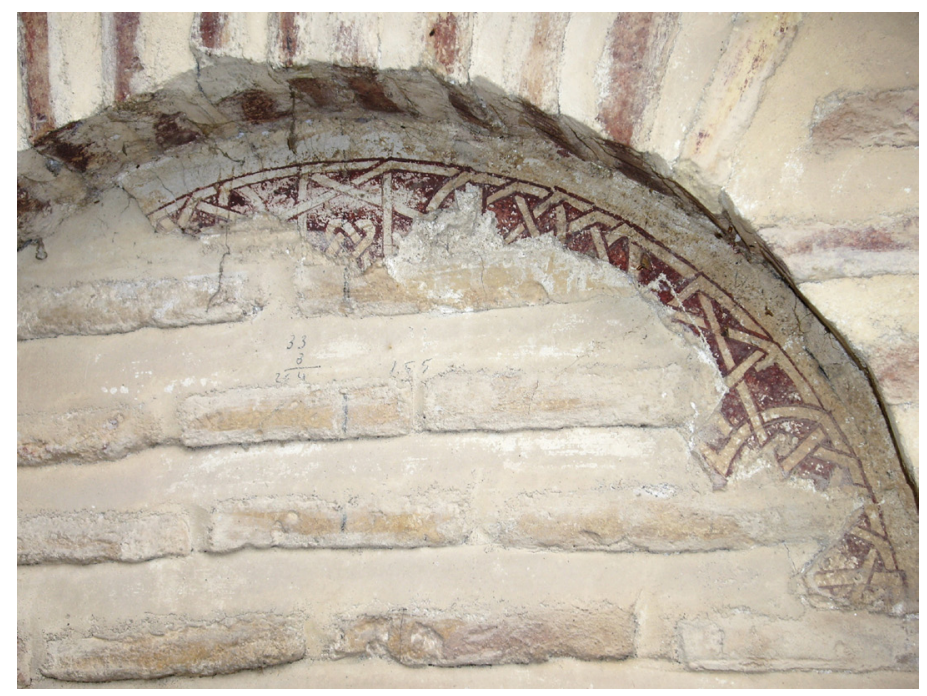

Fig. 6. Ermita del Cristo de la Vega de Toledo. Detalle de su decoración pictórica. Foto del autor.

En Brihuega se conservan restos muy importantes de un gran palacio vinculado con el propio Jiménez de Rada, estudiado por Leopoldo Torres Balbás $^{72}$. Reyes y obispos aparecen por aquellos años en la villa alcarreña, y todo hace pensar que se pudieran dar citar en la residencia del arzobispo ${ }^{73}$. Hoy es conocida como castillo de la Peña Bermeja (fig. 7), donde además de una capilla había estancias palatinas. Desde su exterior se observa una gran arquitectura civil del siglo XIII donde unas pocas ventanas animan su paramento ${ }^{74}$. En su interior aún se conservan vestigios de ricas zocaladas pintadas con lacerías geométricas de raíz andalusí, en donde aparecen también, junto a las cintas rojas, otras de color negro (fig. 8). Podrían relacionarse con otros conjuntos pictóricos como los que se estudian en el Alcázar de Segovia o en la Torre de Hércules de la misma ciudad entre muchos otros. La tradición del zócalo pintado es un gran capítulo artístico que enlaza la cronología completa de la España medieval, independientemente de la confesión religiosa del territorio o promotor ${ }^{75}$. Posiblemente en Brihuega nos encontremos

72 Torres 1941, pp. 4-9.

${ }^{73}$ Gorosterratzu 1925, pp. 334-337; Torres 1941, p. 2, recuerda que se constata documentalmente la presencia de Jiménez de Rada en la villa en 1224, 1228, 1233, 1238 y en 1239; lo cual no excluye que estuviera allí en más ocasiones.

${ }^{74}$ La ubicación en su interior del cementerio antiguo de la villa hizo que todo el conjunto quedase muy alterado.

${ }^{75}$ De la amplia bibliografía de Carmen Rallo Gruss destacamos Rallo 1998, 2002. 
con una de las primeras realizaciones pictóricas "a lo morisco" o de "echar cintas" en un edificio de semejante importancia ${ }^{76}$. Después este tipo de decoración se repetirá una y otra vez en el ornato de todo tipo de construcciones ${ }^{77}$. Brihuega es para nosotros el primer eslabón de una larga cadena que llega al menos hasta el siglo XVI y que se va enriqueciendo poco a poco. Se trata de un edificio con claras alusiones francesas en lo que a la estructura y arquitectura se refiere, parecidas a las que pudiéramos ver en la Francia conocida por Jiménez Rada, tal como nos explica Torres Balbás ${ }^{78}$; en cambio en su interior se abre paso una decoración de clara alusión andalusí. Aquí podemos decir que se inicia el camino artístico de tantas casas y palacios de la corona castellanoleonesa bajomedieval. Brihuega supone el mejor testigo de la realidad y veracidad que vislumbramos en los escritos de Jiménez de Rada. Es muy interesante, además, ver el resto de construcciones eclesiásticas de la época de la misma villa alcarreña, igualmente recordadas en el estupendo artículo de D. Leopoldo Torres Balbás centrado en nuestro arzobispo ${ }^{79}$.

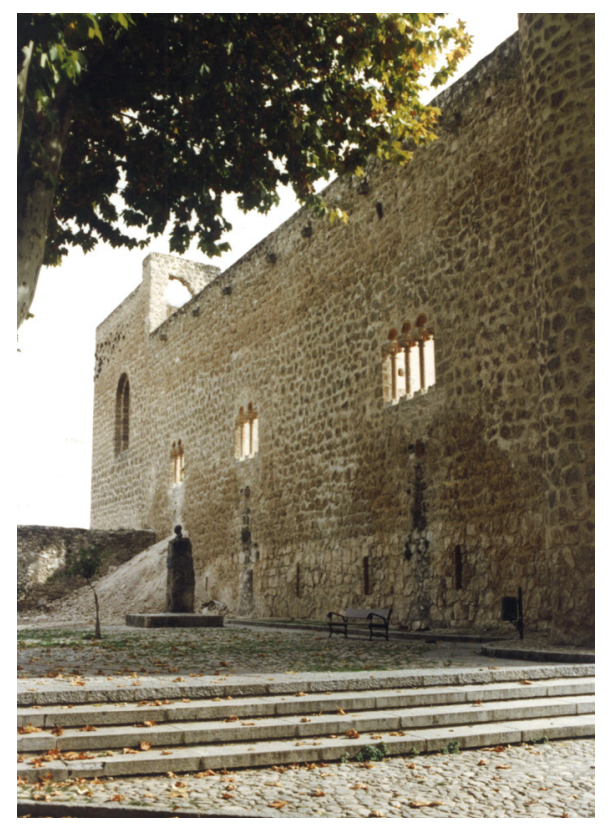

Fig. 7. Castillo de Peña Bermeja. Brihuega. Primera mitad del siglo XIII. Foto del autor.

\footnotetext{
${ }^{76}$ Rallo 2002, pp. 272-275.

${ }^{77}$ Ibidem, pp. 256-379.

${ }^{78}$ Torres 1941 , pp. 5-6.

${ }^{79}$ Ibidem, pp. 9-10.
} 


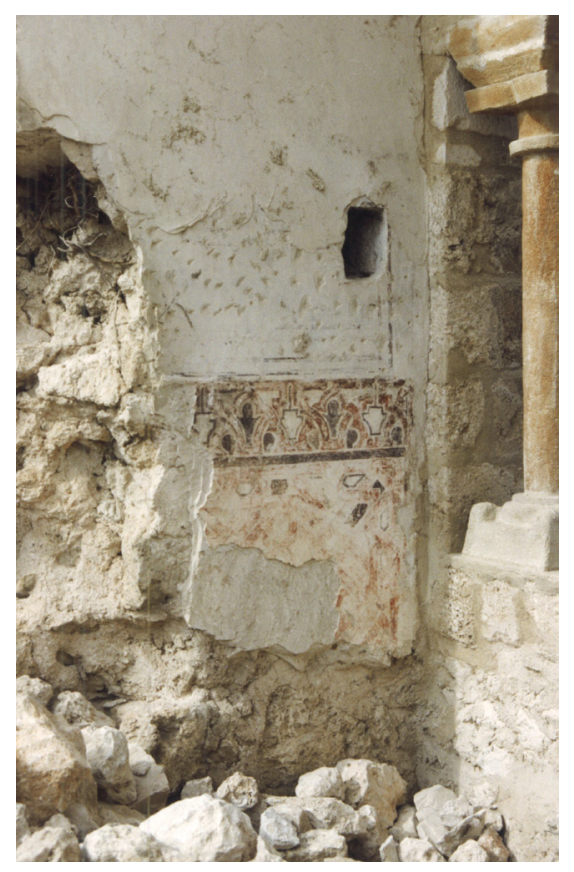

Fig. 8. Castillo de Peña Bermeja. Detalle de la decoración interior. Brihuega. Foto del autor.

El otro elemento al que vamos a referirnos es la cúpula de mocárabes. No es algo decorativo y su utilización, unida a la complejidad de sus diseños, conlleva una asimilación cultural andalusí que va mucho más allá de lo anecdótico. Es necesario introducirse en su significado, vinculado con la idea de la creación, por lo que su aparición en lugares funerarios, en edificios de carácter filantrópico, en espacios regios o en la entrada de edificios, conlleva un claro sentido metafísico de conexión con la eternidad de Dios ${ }^{80}$. No se puede afirmar cuáles pudieron ser las primeras cúpulas de mocárabes andalusíes, pero, de las conservadas, la que se encuentra en la Puerta del Lagarto de la mezquita aljama almohade de Sevilla, fechada a finales del siglo XII, pudiera ser a día de hoy una de las más antiguas. Sorprendentemente, en el primer tercio del siglo XIII vemos su eco en dos cúpulas conservadas en la iglesia de San Andrés de Toledo (figs. 9 y 10), en las que todo parece indicar que se corresponden con dos lugares funerarios ${ }^{81}$.

\footnotetext{
${ }^{80}$ Ruiz 2017, pp. 249-260.

${ }^{81}$ Sobre el uso de las cúpulas de mocárabes véase Ruiz 2000.
} 


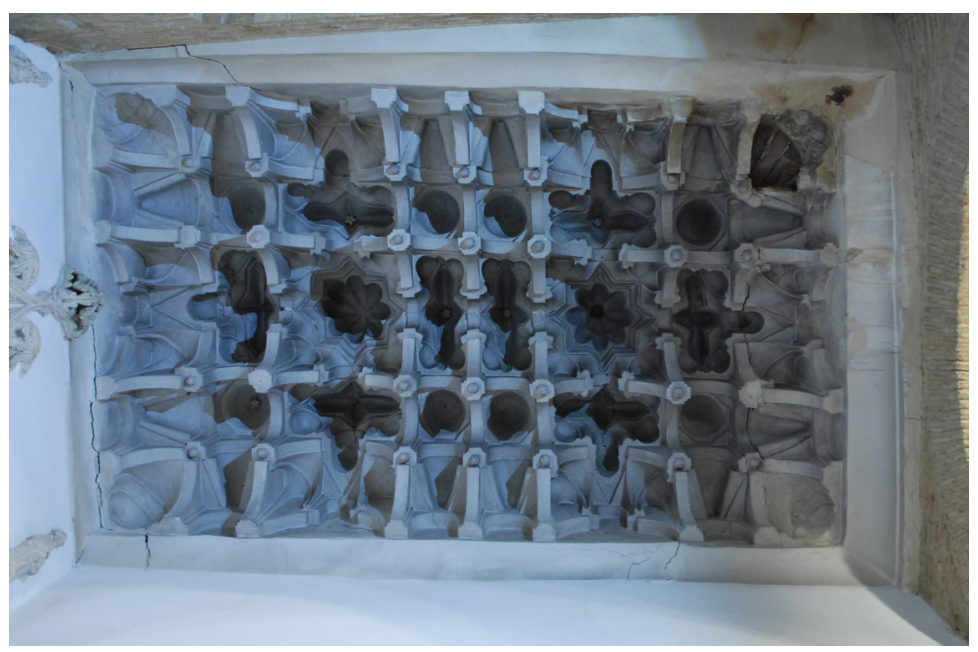

Fig. 9. Cúpula de mocárabes en San Andrés de Toledo. Transepto lado norte. Primera mitad del siglo XIII. Foto del autor.

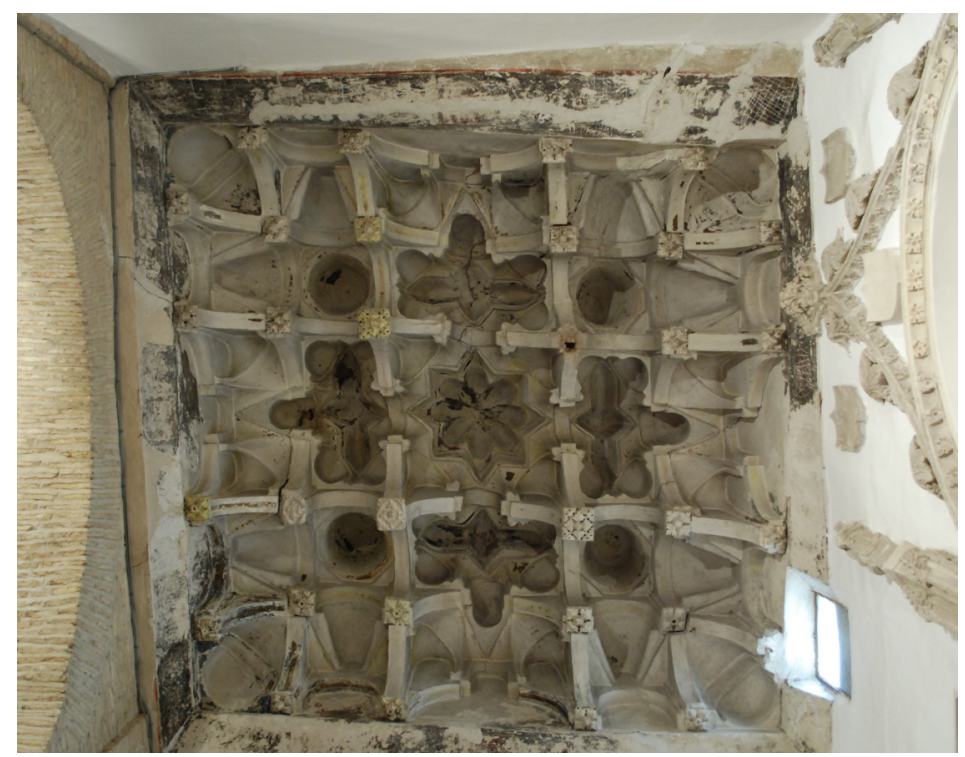

Fig. 10. Cúpula de mocárabes en San Andrés de Toledo. Transepto lado sur. Primera mitad del siglo XIII. Foto del autor.

A partir del segundo cuarto del siglo XIII y tras la conquista cristiana de Córdoba en 1236 se produjo un movimiento historicista neocordobés 
en Toledo, donde la Mezquita de Córdoba se convirtió en un referente de la cultura visual de lo sagrado. La célebre etapa construida por Al-Hakam II en la década de los sesenta del siglo X llegó a la propia catedral toledana, donde los triforios de su presbiterio, girola y lado oriental del transepto exhiben un precioso guiño al edificio cordobés mediante la introducción de arcos polilobulados entrecruzados que emulan, pero no copian, a los de la gran aljama omeya (fig. 11). Lo mismo sucede respecto a las fachadas de muchos de los templos toledanos bajomedievales que siguen los diseños compositivos de las portadas del edificio cordobés ${ }^{82}$.

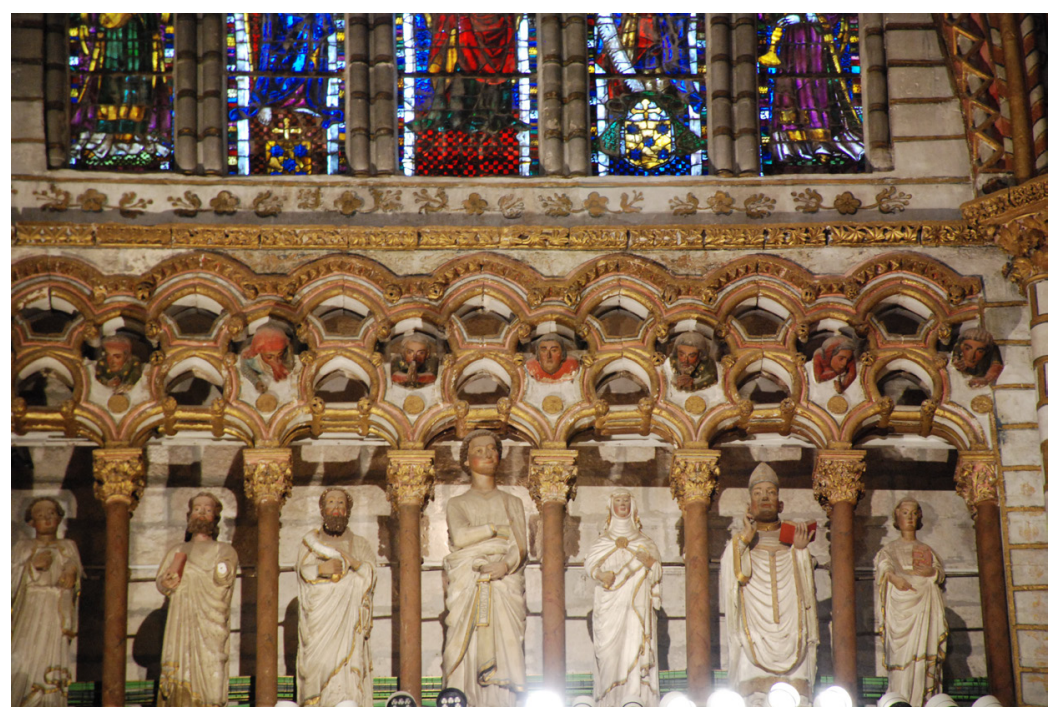

Fig. 11. Catedral de Toledo. Detalle del triforio del presbiterio. Siglo XIII. Foto del autor.

Con estos pocos ejemplos podemos dar por comenzado un camino artístico con gran futuro. En el último tercio del siglo XIII se iniciará la utilización de la yesería andalusí en todo tipo de construcciones y podemos estudiar en el monasterio de las Huelgas Reales de Burgos, en el palacio donde se fundó el convento de Santa Clara de Toledo o en la sinagoga de Santa María la Blanca de la misma ciudad su punto de partida. Poco a poco de lo decorativo pasaremos a la asunción de espacios y mensajes cada vez más complejos ${ }^{83}$.

\footnotetext{
${ }^{82}$ Ruiz 2009.

${ }^{83}$ Ruiz 2004.
} 


\section{REFLEXIÓN FINAL. ARABIZACIÓN E ISLAMIZACIÓN. ALGO QUE FORMA \\ PARTE DE LA ESTORIA DE ESPAÑA NUNCA PODRÁ SER BOTÍN O TROFEO, PERO SÍ TESTIGO DE SU MEMORIA. VIABILIDAD DE UN PROYECTO APARENTEMENTE CONTRADICTORIO}

Cuántos hombres del pasado aparentemente contradictorios son los artífices de los grandes cambios al tener la capacidad de vislumbrar el futuro. Ciertamente Jiménez de Rada fue un protagonista clave en la derrota del imperio almohade en las Navas de Tolosa en 1212 al conseguir de Roma la bula de cruzada, tal como vimos. A pesar de todo ello, Jiménez de Rada es el gran personaje que explicó en su dilatada labor cronística la diversidad histórica de Hispania y valoró los aportes de la cultura andalusi ${ }^{84}$.

Es necesario recordar que al morir Jiménez de Rada en 1247 el aún infante Alfonso contaba ya con 26 años. Cuando se cotejan las obras del arzobispo con las del scriptorium del Rey Sabio se puede observar con gran facilidad cómo el espíritu de Jiménez de Rada estaba muy presente. Comenzábamos estas líneas con la cédula real firmada en Sevilla en 1263 por Alfonso X por la que se garantizaba la conservación deliberada de la mezquita de Córdoba ante su carácter único. Ellos, Jiménez de Rada y Alfonso X, entendieron la necesidad de explicar la diversidad de lo que entendían por Hispania, fruto de una obra colectiva ${ }^{85}$. Pero una cosa es una crónica escrita en el siglo XIII, cuyo público es muy reducido, y otra muy distinta es la creación de espacios arquitectónicos donde esas ideas se puedan hacer presentes. El paisaje monumental a la postre nos habla de la veracidad de un proyecto teórico o, si se prefiere, forma parte de su materialización. Jiménez de Rada es conocido en lo que al arte se refiere por haber iniciado la fábrica gótica más importante del siglo XIII en la península ibérica, con unas formas de vanguardia que se alejaban de la opción tardorrománica, más tradicional, de la catedral de Tarragona, con cuya diócesis siempre mantuvo una gran rivalidad por la primacía en la iglesia peninsular. Pero para nosotros Rada es ante todo el personaje que hizo posible diferenciar entre arabización e islamización. La iglesia de San Román y la comunidad mozárabe de Toledo explican a la perfección el espíritu último del proyecto del arzobispo. Es decir, se podía aceptar toda una España arabizada, su cultura, su ciencia, su lengua y, por supuesto, su memoria. Gracias a ello se pudo conservar la mezquita de Córdoba, la Alhambra de Granada o la Giralda de Sevilla, y entender que dichos edificios fueran parcialmente emulados a lo largo de los siglos en numerosas

${ }^{84}$ Ayala 2017, pp. 210, 214, 217-220. Habla de la importancia de la comunidad mozárabe que desde tiempos de los omeyas pudo reivindicar ese carácter plural de la concepción de Hispania. De nuevo es obligado recordar, Aillet 2010.

${ }^{85}$ Ruiz 2016. 
ocasiones. A los tres edificios se les podía aplicar el mismo texto de la provisión de la Reina Juana I de Castilla donde se habla de la conservación necesaria y digna de la Alhambra. Edificios que crearon sentimientos de pertenencia y que explican que un templo tan simbólico para los reyes como la iglesia de San Jerónimo el Real de Madrid fuera construido en el entorno de 1500 con el aspecto de la torre de Comares de la Alhambra. La ruptura de dichos sentimientos de pertenencia en el siglo XIX provocó que su aspecto original fuera destruido en aras de darle un aspecto neogótico teóricamente más adecuado para un edificio donde se jura al príncipe de Asturias, en un momento sumamente interesante en el que se está debatiendo, a mediados de dicha centuria, el papel del arte en la identidad nacional ${ }^{86}$.

Terminamos con una última reflexión sobre la idea de botín y memoria. Debe cuestionarse la idea de estudiar los objetos de al-Andalus, en particular las artes suntuarias, como expresión de botín ${ }^{87}$. Las ricas telas y los objetos lujosos tienen vida propia, y su misma calidad explica su valoración sin la necesidad de recurrir a otros parámetros ideológicos o confesionales. Un simple vistazo a tesoros catedralicios o a ajuares funerarios demuestra que los ricos objetos, independientemente de su origen, comparten los mismos lugares. Ya se ha aludido al ajuar funerario de Rodrigo Jiménez de Rada compuesto de ricas telas de muy diferentes procedencias, también de al-Andalus. Respecto a los edificios mantenemos la misma idea. La Alhambra de Granada como la mezquita de Córdoba o la Giralda de Sevilla no creemos que deban ser consideradas o estudiadas como botín legitimador, más bien como memoria de los jalones de la historia pasada de la España arabizada ${ }^{88}$. Su conservación reivindicaba la memoria del pasado, lo cual formaba parte de la responsabilidad y virtud de los gobernantes. Pero esa actitud no fue algo ni mucho menos habitual. Hoy resulta muy difícil contemplar grandes obras otomanas en la ciudad de Belgrado o en Grecia, donde se hizo necesario remodelar y dibujar la imagen del pasado en la construcción/invención de sus nuevas identidades nacionales. Las construcciones sicilianas donde se ven inscripciones en árabe, cúpulas de mocárabes y un sinfín de elementos del arte islámico son ya construcciones normandas y, de hecho, no podemos hablar de obras conservadas

\footnotetext{
${ }^{86}$ Ruiz 2001.

${ }^{87}$ Nos gustó mucho el planteamiento general, y muy necesario, de Urquízar 2017, por sus reflexiones respecto a la visión existente en la España moderna sobre el pasado de al-Andalus. Respecto al tema del botín, presentado en ese libro véase Ruiz 2018, p. 609.

${ }^{88}$ Ruiz 2001. Ha sido habitual dotar de una historia a muchos objetos al vincularlos como presa de botín, pero lógicamente no siempre fue así. Hubo piezas que sin duda sí tienen ese valor simbólico, como los yamures (Ruiz 2019) o las campanas de las iglesias, tomados como presa de triunfo. No creemos que fuera el caso ni de los edificios ni de las artes suntuarias, pues su dimensión simbólica la consideramos diferente.
} 
de su periodo islámico de gran envergadura. El caso hispano es distinto, no solo no se realizó una damnatio memoriae del pasado patrimonial sino que se conservó de forma consciente y a su vez pudo ser emulado en construcciones posteriores. Terminamos con una idea que consideramos esencial: un patrimonio que se reivindica como parte de la Estoria de España, recordando el nombre de la crónica alfonsí, nunca podrá ser considerado como botín o trofeo por ningún proyecto político que surja de la misma ${ }^{89}$. Rodrigo Jiménez de Rada, gracias a que fue muy consciente de la diferencia ideológica y cultural existente entre arabización e islamización, posibilitó que el patrimonio de al-Andalus generase los sentimientos de pertenencia necesarios e imprescindibles que hicieron posible su valoración primero y su conservación después. Sentimientos colectivos de pertenencia que la Mezquita de Córdoba, la Giralda de Sevilla o la Alhambra de Granada suscitaron en el pasado y continúan generando en el presente, gracias al proyecto que se forjó en el siglo XIII por Rodrigo Jiménez de Rada, quien supo ver en la comunidad mozárabe de Toledo el pasado, el presente y el futuro.

\section{BIBLIOGRAFÍA CITADA}

Abad Castro, Concepción (1991), Arquitectura mudéjar religiosa en el arzobispado de Toledo, Toledo, Diputación de Toledo.

Abad Castro, Concepción (2004), La iglesia de San Román de Toledo, Madrid, Iberdrola.

Aillet, Cyril (2010), Les mozárabes. Christianisme, islamisation et arabisation en péninsule ibérique (IX ${ }^{e}-X I I^{e}$ siècle), Madrid, Casa de Velázquez.

Ayala Martínez, Carlos de (2007), Realidad y percepción de Hispania en la Edad Media, "eHumanista" 37, pp. 206-231.

Balmelle, Catherine; Blanchard-Lemée, Michèle; Christophe, Jeannine; Darmon, Jean-Pierre; Guimier-Sorbets, Anne-Marie; Lavagne, Henri; Prudhome, Richard; Stern, Henri (1985), Le décor géométrique de la mosaïque romaine. Répertoire graphique et descriptive des compositions linéaires et isotropes, París, Picard.

Bango Torviso, Isidro G. (1985), L'Ordo Gothorum et sa survivance dans l'Espagne du Haut Moyen Age, "Revue de l'Art" 70, pp. 9-20.

\footnotetext{
${ }^{89}$ Ruiz 2001. Ha sido habitual dotar de una historia a muchos objetos al vincularlos como presa de botín, pero lógicamente no siempre fue así. Hubo piezas que sin duda sí tienen ese valor simbólico, como los yamures (Ruiz 2019) o las campanas de las iglesias, tomados como presa de triunfo. No creemos que fuera el caso ni de los edificios ni de las artes suntuarias, pues su dimensión simbólica la consideramos diferente.
} 
Bango Torviso, Isidro G. (2008), Los expolios del paisaje monumental y la arquitectura hispana de los siglos VII al XI. Reflexiones sobre el proceso constructivo de San Miguel de Escalada, "De Arte" 7, pp. 7-50.

Buresi, Pascal; Van Staëvel, Jean-Pierre; Fili, Abdallah; Saleh Ettahiri, Ahmed; Urvoy, Dominique; Juan García, Antonio de; Retuerce, Manuel; Elkhammar, Abdeltif; Ghouirgate, Mehdi; Déléry, Claire; Cressier, Patrice (2014), Les almohades ou la refondation d'un empire autour d'un nouveau dogme religieux (vers 1116-1269), en Lintz, Yannick (com.), Maroc médiéval. Un empire de l'Afrique à l'Espagne, du 17 octobre 2014 - 19 janvier 2015, París, Musée du Louvre, pp. 248-421.

Calvo Capilla, Susana (2008), La ampliación de la Mezquita de Córdoba: Mensajes, formas y funciones, "Goya" 323, pp. 89-106.

Calvo Capilla, Susana (2012), Madinat al-Zhara y la observación del tiempo: el renacer de la Antigüedad Clásica en la Córdoba del siglo X, en 711: El Arte entre la Hégira y el Califato Omeya de al-Andalus. V Jornadas Complutenses de Arte Medieval, "Anales de Historia del Arte" 22/2, pp. 131-160,

Calvo Capilla, Susana (2014), Images and Knowledge of Classical Antiquity in the Palace of Madinat al-Zahra' (Cordoba, 10 th century): Its Role in the Construction of the Caliphal Legitimacy," Muqarnas", pp. 1-33.

Castiñeiras, Manuel (2010), Didacus Gelmirius, patrono de las artes. El largo camino de Compostela: de periferia a centro del Románico, en Castiñeiras, Manuel (dir.), Compostela y Europa. La historia de Diego Gelmírez, Milán, Skira, pp. 32-97.

Crónica del Moro Rasis, eds. Diego Catalán, María Soledad de Andrés, Madrid, Gredos, 1975.

Don Juan Manuel, El Conde Lucanor, en Blecua, José Manuel (ed.), Obras completas de Don Juan Manuel, vol. II, Madrid, Gredos, 1981.

Doods, Jerrilynn (2007), Rodrigo, Reconquest, and Assimilation: some preliminary thoughts about San Román, en Hourihane, Collum (ed.), Spanish Medieval Art. Recent studies, Princeton, Arizona Center for Medieval and Renaissance Studies - The Index of Christian Art, pp. 215-244.

Fernández-Ordóñez, Inés (2000), La transmisión textual de la "Estoria de España" y de las principales "crónicas" de ella derivadas, en Fernández-Ordóñez, Inés (ed.), Alfonso X El Sabio y las crónicas de España, Valladolid, Universidad de Valladolid, pp. 219-260.

Fernández-Ordóñez, Inés (2002), La técnica historiográfica del Toledano. Procedimientos de organización del relato, "Cahiers de Linguistique et de Civilisation Hispaniques Médievales" 26/1, pp. 187-221. 
Fernández Valverde, Juan (1995), El personaje, en Mantilla de los Ríos y Rojas, María Socorro (coord.), Vestiduras pontificales del Arzobispo Rodrigo Ximénez de Rada. S. XIII. Su estudio y restauración, Madrid, Ministerio de Cultura, pp. 17-25.

García García, Francisco de Asís (2018), Las portadas de la catedral de Jaca. Reforma eclesiástica y poder real a finales del siglo XI, Huesca, Instituto de Estudios Altoaragoneses.

Gómez-Moreno, Manuel (1892), Guía de Granada, Granada, Imprenta de Indalecio Ventura.

Gómez-Moreno, Manuel (1906), Excursión a través del arco de herradura, Madrid, Imprenta Ibérica.

González Palencia, Ángel (1930), Los mozárabes de Toledo en los siglos XIIXIII, Madrid, Instituto Valencia de Don Juan.

Gorosterratzu, Javier (1925), Don Rodrigo Jimenez de Rada. Gran estadista, escritor y prelado, Pamplona, Imprenta y Librería de viuda de T. Bescansa.

Grassotti, Hilda (1972), Don Rodrigo Ximénez de Rada, gran señor y hombre de negocios en la Castilla del siglo XIII, "Cuadernos de Historia de España" 55-56, pp. 1-302.

Grupo Ailbe (2011), San Román de Toledo [en línea], http://www.circulo-romanico.com/index.php?menu_id=5\&jera_id=2366\&page id $=1878 \&$ cont id $=4407$ [consulta: $14 / 05 / 2020$ ].

Jiménez de Rada, Rodrigo, Estoria de los árabes, ed. Fernando Bravo López, Córdoba, UCOPress, 2019.

Jiménez de Rada, Rodrigo, Historia de Rebvs Hispanie sive Historia Gothica, ed. Juan Fernández Valverde, Turnhout, Brepols, 1987.

Jiménez Martín, Alfonso (1998), Notas sobre el alminar de la Aljama de Isbiliya, en VIII Centenario de la Giralda (1198-1998), Córdoba, Cajasur - Universidad de Sevilla, pp. 31-43.

Linehan, Peter; Hernández, Francisco J. (2004), The Mozarabic cardinal: the life and times of Gonzalo Pérez Gudiel, Firenze, SISMEL - Edizione del Galluzzo.

Lomax, Derek W. (1977), Rodrigo Jiménez de Rada como historiador, en Actas del Quinto Congreso de la Asociación internacional de Hispanistas: celebrado en Burdeos del 2 al 8 de septiembre de 1974, Burdeos: Instituto de Estudios Ibéricos e Iberoamericanos, vol. III, Burdeos, Université de Bordeaux, pp. 587-592.

Mantilla de los Ríos y Rojas, María Socorro (coord.) (1995), Vestiduras pontificales del Arzobispo Rodrigo Ximénez de Rada. S. XIII. Su estudio y restauración, Madrid, Ministerio de Cultura. 
Martínez de Aguirre Aldaz, Javier (2011), Arquitectura y soberanía: la catedral de Jaca y otras empresas constructivas de Sancho Ramírez, "Anales de Historia del Arte" vol. extr. 2, pp. 181-249.

Maser, Matthias (2006), Die Historia Arabum des Rodrigo Jiménez de Rada, Berlín, Lit Verlag.

Maser, Matthias (2012), Rodrigo Jiménez de Rada and his Historia Arabum: an extraordinary example of inter-cultural tolerance, en Lambert, Sarah; Nicholson, Helen (eds.), Languages of love and hate. Conflict, communication, and identity in the medieval Mediterranean, Turnhout, Brepols, pp. 223-238.

Nieto Cumplido, Manuel (1980), Corpus Medieavale cordubense, II, (12561277), Córdoba, Ayuntamiento de Córdoba.

Peña, Antonio (2010), Estudio de la decoración arquitectónica romana y análisis del reaprovechamiento de material en la mezquita aljama de Córdoba, Córdoba, UCOpress.

Pérez Higuera, María Teresa (1992), Ermita del Cristo de la Vega, en Péris Sánchez, Diego (coord.), Arquitecturas de Toledo, vol. I, Toledo, Junta de Comunidades de Castilla La Mancha, pp. 204-209.

Pérez Monzón, Olga (2012), "Ninguno non sea osado de tomar pilares nin columnas nin otras piedras... para fazer delas otra labor". Sobre el aprecio a la cultura artística en el periodo bajomedieval, "Medievalismo" 22, pp. 153-184.

Pick, Lucy K. (2004), Conflict and Coexistence. Archbishop Rodrigo and the Muslims and Jews of Medieval Spain, Ann Arbor, The University of Michigan Press.

Poza Yagüe, Marta (2014), Arte e ideología. Roma y Aragón a finales del siglo XI: la antigüedad clásica como mecanismo de legitimación de un nuevo reino, en De María, Sandro; Parada López de Corselas, Manuel (eds.), El Imperio y las Hispanias de Trajano a Carlos V, Bolonia, Bononia University Press, pp. 185-198.

Prado, Germán (1928), Historia del Rito Mozárabe y Toledano, Santo Domingo de Silos, Abadía de Santo Domingo de Silos.

Primera Crónica General de España, eds. Ramón Menéndez Pidal, Diego Catalán, Madrid, Gredos, 1977.

Rallo Gruss, Carmen (1998), Aportaciones de un texto en el Boletín de la Academia a la pintura mudéjar, "Academia" 87, pp. 241-283.

Rallo Gruss, Carmen (2002), Aportaciones a la técnica y estilística de la pintura mural en Castilla a final de la Edad Media. Tradición e influencia mudéjar, Madrid, Fundación Universitaria Española.

Rodríguez Peinado, Laura (2019), El Mediterráneo y la internacionalización de la producción textil medieval, en Rodríguez Peinado, Laura; 
García García, Francisco de Asís (eds.), Arte y producción textil en el Mediterráneo medieval, Madrid, Polifemo, pp. 17-50.

Rubio Sadia, Juan Pablo (2006), El cambio de rito en Castilla: su iter historiográfico en los siglos XII y XIII, "Hispania Sacra” 58, pp. 9-35.

Ruiz Souza, Juan Carlos (2000), La cúpula de mocárabes y el Palacio de los Leones de la Alhambra, "Anuario del Departamento de Historia y Teoría del Arte" 12, pp. 9-24.

Ruiz Souza, Juan Carlos (2001), Botín de guerra y tesoro sagrado, en Bango Torviso, Isidro G. (com.), Maravillas de la España Medieval. Tesoro Sagrado y Monarquía, Catálogo de la exposición celebrada en la Colegiata de San Isidoro de León entre el 18 de diciembre de 2000 y el 28 de Febrero de 2001, Valladolid, Junta de Castilla y León, pp. 31-40.

Ruiz Souza, Juan Carlos (2004), Castilla y Al-Andalus. Arquitecturas aljamiadas y otros grados de asimilación, "Anuario del Departamento de Historia y Teoría del Arte" 16, pp. 17-43.

Ruiz Souza, Juan Carlos (2009), Toledo entre Europa y Al-Andalus en el siglo XIII: Revolución, tradición y asimilación de las formas artísticas en la Corona de Castilla, "Journal of Medieval Iberian Studies" 1/2, pp. 233-271.

Ruiz Souza, Juan Carlos (2014), Rodrigo Jiménez de Rada, Alfonso X y Pedro I ante las "reliquias arquitectónicas" del pasado en la construcción de la identidad de España. Historicismos antiguos, en Teijeira Pablos, María Dolores; Herráez Ortega, María Victoria; Cosmen Alonso, María Concepción (coords.), Reyes y prelados: la creación artística en los reinos de León y Castilla (1050-1500), Madrid, Silex, pp. 219-230.

Ruiz Souza, Juan Carlos (2016), Al-Andalus e Hispania en la identidad del arte medieval español. Realidad y desenfoque historiográfico, en Franco, Borja; Pomara, Bruno; Lomas, Manuel; Ruiz, Bárbara (eds.), Coexistencia y conflictos interreligiosos en el Mediterráneo (ss. XIV-XVIII), Valencia, Universitat de Valencia, pp. 375-394.

Ruiz Souza Juan Carlos (2017), Egipto, Granada y Castilla: estrategias y convergencias en la arquitectura del poder, en Calvo Capilla, Susana (ed.), Las artes en Al-Andalus y Egipto. Contextos e intercambios, Arte y Contextos II, Madrid, La Ergástula, pp. 207-231.

Ruiz Souza, Juan Carlos (2018), Reseña. Urquízar-Herrera, Antonio, Admiration \& Awe. Morisco Buildings and Identity Negotations in Early Modern Spanish Historiography, Oxford, Oxford University Press, 2017, “Al-Qantara”39/2, pp. 607-612.

Ruiz Souza, Juan Carlos (2019), Yamures. Reutilización y significado en el paisaje monumental cristiano, en Vidal, Sergio (com.), Las artes 
del metal en al-Andalus, Madrid, Ministerio de Cultura y Deporte, pp. 40-43.

Schattner, Thomas G.; Valdés Fernández, Fernando (eds.) (2009), Spolien im umkreis der macht/Spolia en el entorno del poder, Madrid, Diputación de Toledo.

Serrano Coll, Marta (2018), Tarragona y la romanidad de su comunidad catedralicia en la Edad Media, en Arciniega, Luis; Serra, Amadeo (eds.), Recepción, Imagen y memoria del arte del pasado, "Quaderns Ars Longa" 7, pp.71-100.

Souto, Juan Antonio (2011), Los textos árabes en la Iglesia de San Román de Toledo, "Círculo románico" [en línea], http://www.circulo-romanico. com/index.php?menu_id=5\&jera_id=2366\&page_id $=1878 \&$ cont id=4492 [consulta: $14 / 05 / 2020]$.

Torres Balbás, Leopoldo (1941), La Capilla del Castillo de Brihuega y las edificaciones de Don Rodrígo Jiménez de Rada, "Archivo Español de Arte" 45, pp. 1-23.

Urquízar-Herrera, Antonio (2017), Admiration \& Awe. Morisco Buildings and Identity Negotations in Early Modern Spanish Historiography, Oxford, Oxford University Press.

Fecha de recepción del artículo: julio 2020

Fecha de aceptación y versión final: marzo 2021 
